\title{
The prevalence of iridologic signs in individuals with Diabetes Mellitus*
}

\author{
A prevalência de sinais iridológicos em indivíduos com Diabetes Mellitus \\ La prevalencia de signos iridológicos en individuos con Diabetes Mellitus
}

\section{Léia Fortes Salles ${ }^{1}$, Maria Júlia Paes da Silva ${ }^{2}$, Eutália Aparecida Cândido de Araújo $^{3}$}

\begin{abstract}
Objective: To verify the prevalence of iridologic signs, such as the pancreas sign and the Cross of Andreas, in individuals with Diabetes mellitus and the association of these signs with three risk factors for the disease: obesity, sedentarism and heredity. Methods: Collection occurred from April to June, 2006, involving 97 individuals over 30 years of age with Diabetes mellitus, cared for at Centro de Saúde Escola "Geraldo de Paula Souza", São Paulo. Results: After having their irises analyzed, the adjusted prevalence of the pancreas sign and the Cross of Andreas was observed, with $98 \%$ and $89 \%$, respectively. There were significant associations $(\mathrm{p}<0.001)$ between obesity, sedentarism and family history for diabetes with both signs studied. Conclusion: Evidence shows data of interest for the preventive area and the necessity for new studies.
\end{abstract}

Descriptors: Diabetes mellitus/prevention \& control; Iridology; Nursing research

\section{RESUMO}

Objetivo: Verificar a prevalência de sinais iridológicos, como o sinal do pâncreas e Cruz de Andréas em indivíduos com Diabetes mellitus e a associação destes sinais com os três fatores de risco para a doença: obesidade, sedentarismo e hereditariedade. Métodos: A coleta ocorreu de abril a junho de 2006, com 97 indivíduos de idade superior a 30 anos e portadores de Diabetes mellitus, atendidos no Centro de Saúde Escola "Geraldo de Paula Souza", São Paulo. Resultados: Após análise das íris, verificou-se que a prevalência ajustada do sinal do pâncreas e da Cruz de Andréas, foram respectivamente, 98\% e 89\%. Houve associações significativas ( $<<0,001)$ entre obesidade, sedentarismo e antecedente familiar para diabetes com ambos os sinais estudados. Conclusão: As evidências demonstram dados de interesse para a área preventiva e a necessidade de realização de novos estudos.

Descritores: Diabetes mellitus/prevenção \& controle; Iridologia; Pesquisa em enfermagem

\section{RESUMEN}

Objetivo: Verificar la prevalencia de signos iridológicos, como la señal del páncreas y Cruz de Andreas en individuos con Diabetes mellitus y la asociación de estos signos con los tres factores de riesgo para la enfermedad: obesidad, sedentarismo y herencia. Métodos: La recolección de datos se llevó a cabo de abril a junio del 2006, con 97 individuos de edad superior a 30 años y portadores de Diabetes mellitus, atendidos en el Centro de Salud Escuela "Geraldo de Paula Souza", Sao Paulo. Resultados: Después del análisis de las iris, se verificó que la prevalencia ajustada de la señal del páncreas y de la Cruz de Andreas, fueron respectivamente, 98\% y 89\%. Hubo asociaciones significativas $(\mathrm{p}<0,001)$ entre obesidad, sedentarismo y antecedente familiar para la diabetes con ambas señales estudiadas. Conclusión: Las evidencias muestran datos de interés para el área preventiva y la necesidad de realización de nuevos estudios.

Descriptores: Diabetes mellitus/prevención \& controle; Iridología; Investigación en enfermería

\footnotetext{
* Research extracted from the Master's Thesis - 2006, with field research performed at Centro de Saúde Escola "Geraldo de Paula Souza", at Faculdade de Saíde Pública of Universidade de São Paulo - USP - São Paulo (SP), Bražil.

${ }^{1} \mathrm{RN}$, Specialist in Iridology and Irisdiagnosis by Faculdade de Ciências de São Paulo and Instituto Brasileiro de Estudos Homeopáticos. Student at the Nursing Graduate Program in Adult Healthcare of Escola de Enfermagem da Universidade de São Paulo USP - São Paulo (SP), Brazil.

${ }^{2}$ Full Professor of Departamento de Enfermagem Médico-Cirúrgica at Escola de Enfermagem da Universidade de São Paulo USP - São Paulo (SP), Brazil. ${ }^{3}$ Ph.D in Public Health by Universidade de São Paulo. Statistics advisor of Escola de Enfermagem da Universidade de São Paulo USP - São Paulo (SP), Brazil.
} 


\section{INTRODUCTION}

The largest contribution of the development of new knowledge in genetics lies in the area of disease prevention, which should become the main focus of modern Medicine. While some diseases have their only causal factor in the genetic component, others, such as diabetes, are determined by multiple genetic factors, interacting among themselves and with environmental factors. Therefore, genetic susceptibility may be lessened by environmental changes, such as changes in eating habits ${ }^{(1)}$.

Iridology shares this idea and, by examining the iris, seeks to determine the location and nature of possible disturbances in the organism and, therefore, to detect predispositions to certain pathologies, identifying risk groups early and orienting them for prevention.

Iridology means the study of the iris, and Irisdiagnosis is a science that permits knowledge about physical, emotional and mental aspects of the individual through the iris ${ }^{(2)}$

Iridology is one of the Complementary Healthcare Practices (CHPs) based on the holistic comprehension of the human being. The holistic approach states that totalities represent more than the sum of their parts. These totalities may be biologic organisms, organizations, societies or scientific-theoretical complexes.

Nursing, as a science of caring, makes use of the holism inherent to its history and philosophy. The roots of Holistic Nursing emerged from Florence Nightingale's visionary notes in her book "Notes about Nursing", in $1860^{(3)}$. Later, in the same branch, theories by the nurses Marta E. Rogers and Jean Watson are published in 1970 and 1979, respectively ${ }^{(4-5)}$. Both stated that caring should be integral and that prevention is one of several aspects of this process.

Following the global tendency and increased search for CHPs, nurses become interested in studying these practices and nursing schools offer space for courses addressing this field of knowledge.

The iris is a hologram, a part that represents the whole. The organism is represented in the iris, as well as in the palm, the sole and the earlobe. The more irregularities are seen in the silky tissue of the iris, the lower the individual's vitality and resistance, and the farthest he is from well-being ${ }^{(2)}$.

There is a very low amount of articles about Iridology. A literature review about the topic from 1970 to 2005 found only 25 articles, four of them published by Brazilian authors. This literature review used the following databases: EMBASE, PubMed, MEDLINE, LILACS, Universidade de São Paulo's central library - Dedalus, PeriEnf, SibiNet. As for the categories, one was a literature review, 12 were research studies and 12 covered updates, histories or editorials. Only half was based on research, not always with an adequate methodology, such as nonrandomized studies, without a detailed description of the method (which does not allow for replication) and with small or convenience samples. The only review about the topic, written in 1999, referred to only four literature authors. Fifteen articles were in favor of the method and 10 against, which made the authors conclude that new research studies, within the methodological rigor, are necessary in this area, since Iridology brings hope in the preventive field ${ }^{(6)}$. Most articles with negative opinions about the method argue that Iridology was not shown to be capable of asserting this or that diagnosis. However, those who know the method know that Iridology does not diagnose; instead, it shows the weakest organs, those that are more likely to fall ill ${ }^{(6)}$.

The iris is a micro system, completely formed at age six, which allows the iridologist to perform a prophylactic and therapeutic approach, through pre-diagnosis ${ }^{(2)}$. Once the signals of jeopardy are detected, these organs should be investigated with specific exams to eliminate the possibility of certain diseases.

The biggest trump of Irisdiagnosis lies in the prevention of diseases, since it is possible for the iridologist to detect signs of risk well before the individual presents symptoms, and use means to maintain the homeostasis of the organism, reducing its possibility of falling ill. As such, it acts in health maintenance as well as disease prevention, which is extremely important for both the individual and society ${ }^{(2,7-8)}$.

In the condensed map of Iridology (Attachment 1), the pancreas is located in the right iris at 7 o'clock (comparing it with a clock face). Signs showing a lowered tissue density, such as the opening of fibers, indicate the organ's debility. When a shock organ is identified, it can only be said that said organ is weaker and likely to fall $\mathrm{ill}^{(2)}$. It is not possible to predict which disease the individual has, had or will have. Therefore, if this sign is the pancreas, it cannot be said whether the disease to be developed will be pancreatitis, a tumor or diabetes.

The presence of the Cross of Andreas (attachment 2), a sign studied by German Iridology, indicates endocrine and exocrine dysfunctions in the pancreas. Patients with this sign usually have incorrect eating habits and hardly ever accept dietary changes ${ }^{(8)}$. The Cross of Andreas can be visualized in both eyes, in the shape of four gaps (fiber openings), disposed at 10,20, 40 and 50 minutes, comparing the iris to a clock face. These gaps also mean tissues that are less dense and weaker, likely to fall ill.

The main pancreatic dysfunction is Diabetes mellitus, a chronic-degenerative disease as old as humanity itself, which is a consequence of lack of insulin or inability of the insulin to perform its functions adequately. It is characterized by chronic hyperglycemia, frequently accompanied by dislipidemia, hypertension and 
endothelial dysfunctions ${ }^{(9)}$.

Democratically distributed, it afflicts both the rich and the poor in different places of the planet. However, it is common in urban and industrial societies, which are usually sedentary and have inadequate dietary habits, with an exaggerated consumption of food rich in carbohydrates and low in fiber. It is usually a disease that advances slowly and surreptitiously. When the first symptoms appear, it may already be too late: infarction, kidney failure, blindness, paralysis, leg or foot amputation and sexual impotence are among its most devastating effects $^{(10)}$.

According to the World Health Organization (WHO), at least one in every ten deaths of adults aged 35-64 can be attributed to diabetes in developed countries and, in some regions, this ratio can be as high as $1: 5^{(11)}$. The mortality data obtained from death certificates underestimate the importance of mortality by diabetes ${ }^{(12)}$.

The WHO estimates that, in 2030, diabetes will be an epidemic (366 million). Nowadays, there are nearly 171 million individuals diagnosed with diabetes in the world, with 5 million in Brazil alone ${ }^{(13)}$, where $8 \%$ of the population between 30 and 69 years old living in metropolitan areas present the disease, with $90 \%$ of type 2 , associated to bad habits of modern life ${ }^{(14)}$.

Data from the Ministry of Health reveal that $50 \%$ of Brazilian diabetic individuals do not know about their condition, therefore remaining without treatment, which explains the fact that several of them present complications of the disease at the moment they are diagnosed $^{(14)}$.

Globally, the direct costs for diabetes healthcare vary from $2.5 \%$ to $15 \%$ of national healthcare expenditure, depending on the local prevalence of the disease and the complexity of the available treatment. Besides the cost in money, diabetes has other costs, associated to pain, anxiety, inconvenience and lower quality of life, which affect patients and their families ${ }^{(15)}$.

Finally, the prevention of Diabetes mellitus is a public healthcare issue nowadays, and should join the identification of risk groups, diagnostics and early treatment, aiming to decrease the distressing effects of the disease.

The prevention strategy most often used in Brazil is the attempt to restore biological normalcy, especially through the modification of risk factors like obesity and sedentarism; however, it is said that, if it were possible to identify the individuals more likely to be afflicted, these strategies would be much more effective ${ }^{(12)}$.

Most studies performed by nurses have found concerns about diabetes prevention, but not about preventing the disease itself, instead focusing on the complications the lack of glucose control can cause ${ }^{(16-17)}$.

The only study found about Iridology and Diabetes mellitus was done by Ruas(10), a homeopathic physician and iridologist. In her study "Diabetes mellitus and the Cross of Andreas", she concludes that this sign is present in $76 \%$ of diabetes patients, in both genders, especially in the 61-70 age range.

Due to everything the diabetes diagnosis represents for the patient and society, it becomes indispensable to contribute in order to avoid its manifestation and early diagnosis.

\section{JUSTIFICATION FOR THE STUDY}

The first author of this study is a specialist in Iridology and Iris diagnosis. Iris diagnosis can be a possibility of prevention and should not be discarded. In the past, there was much controversy caused by techniques like acupuncture and homeopathy. They were victims of unfair accusations and, today, after several studies, are considered medical specialties, since 1980 and 1995, respectively.

The lack of scientific literature about the topic also demonstrates that it is necessary to study it better. There is legal support to use it, since COFEN resolution \# 197/ 97 allows the nurses to use alternative techniques when performing care ${ }^{(18)}$.

Law \#13.717 $7^{(19)}$, from January 8, 2004, by the city hall of São Paulo, on the implementation of Natural Therapies in the Municipal Healthcare Secretariat, including Iris diagnosis, reinforces the credibility of the method.

Finally, there are no systematized studies about the prevalence of iridological signs on Diabetes mellitus, and this is what the present study aims to do. If signs indicating problems in the pancreas can be identified in the iris, preventive measures can then be adopted to reduce the emergence of diabetes and the installation of its sequels, which is extremely relevant, since the problems the disease causes are wide-ranging and cover all aspects - physical, psychic, emotional, social and economic.

\section{OBJECTIVES}

- Establish the prevalence of iridological signs, such as the sign of the pancreas and the Cross of Andreas, in individuals with Diabetes mellitus.

- Verify whether these symptoms are associated with obesity, sedentarism and family history for the disease, risk factors for the pathology.

\section{METHODS}

This is an exploratory, descriptive, cross-section field study with a quantitative approach.

The research was performed at the Centro de Saúde Escola "Geraldo de Paula Souza", at Faculdade de Saúde 
Pública of Universidade de São Paulo, from April $5^{\text {th }}$ to June $3^{\text {rd }}$, after being approved by the Research Ethics Committee of Escola de Enfermagem at Universidade de São Paulo (Process \#500/2005/CEP-EEUSP).

Ninety-seven patients registered and cared for at Centro de Saúde Escola participated in the study. All patients had a diabetes diagnosis and were over 30 years old. They all agreed to participate in the study by signing the term of consent.

Data were collected by the author, who is a nurse and a specialist in Iridology, through interviews (identification and clinical record with questions on weight, height, physical activity and family history for the disease) and photographs of the iris. The images of $L$ and $R$ irises were collected with a digital camera connected to an iridological lens with adequate lighting. The photographs were recorded on individual floppy disks.

All records, as well as the floppies with the images of the irises, were evaluated by the specialist author and validated by a physician, also a specialist in the subject, with books published about the theme $e^{(2,7)}$.

The Cross of Andreas sign, specific for Diabetes mellitus, is positive when 4 fiber openings appear, as shown in Attachment 2, in one of the irises. The sign in the area of the pancreas, indicating the organ's debility, is positive when the $\mathrm{R}$ iris presents fiber openings in this place (at 7 o'clock, if the iris is compared with a clock face).

The data were sent to a specialized professional for statistical analysis. The following procedures were used for data processing:

- Descriptive analysis to know the sample: mean, median, standard deviation, minimum and maximum for quantitative variables;

- Calculation of relative frequencies for the categorical variables;

- Estimate of the prevalence of the signs of the pancreas and the Cross of Andreas, adjusted by gender and age, considering the population of diabetic patients cared for at the CSE "Geraldo de Paula Souza", and the prevalence of both signs in the same individual;

For the inferential analyses, the following procedures were used:

- Non-parametric tests (Kruskal-Wallis and MannWhitney), to compare the sign of the pancreas and the Cross of Andreas, according to the categories of the variables of interest;

- Logistic Regression Models to establish the association between each iridologic sign studied and the variables gender, age, Body Mass Index (BMI), physical activity and family history.

\section{RESULTS}

After analyzing the data, the following sociodemographic characterization of the diabetes patients cared for at Centro de Saúde Escola "Geraldo de Paula Souza" was obtained: Regarding gender, $61.9 \%$ were female, and $38.1 \%$ were male. Most patients involved in the study were between 50 and 79 years old $(73.2 \%)$.

In the group studied, the BMI oscillated between preobesity and obesity 1. Regarding physical activity, 68\% of the individuals were sedentary and $32 \%$ were active, according to the classification of the Center for Disease Control - American College of Sports Medicine. Most individuals in this research mentioned having a diabetic parent.

Table 1 - Presence of the sign of the pancreas and the Cross of Andreas in the iris of the individuals studied. São Paulo, SP - April-June, 2006

\begin{tabular}{lrrrr}
\hline & \multicolumn{2}{c}{ Sign of the pancreas } & \multicolumn{2}{c}{ Cross of Andreas } \\
\cline { 2 - 5 } & $\mathbf{N}$ & $\mathbf{0}$ & $\mathbf{N}$ & $\mathbf{\%}$ \\
\hline Present & 95 & 97.9 & 87 & 89.7 \\
Absent & - & - & - & - \\
Loss of data & 2 & 2.1 & 10 & 10.3 \\
\hline Total & $\mathbf{9 7}$ & $\mathbf{1 0 0 . 0}$ & $\mathbf{9 7}$ & $\mathbf{1 0 0 . 0}$ \\
\hline
\end{tabular}

Table 1 shows that almost $100 \%$ of the diabetic individuals present the sign of the pancreas.

As for the Cross of Andreas, $89.7 \%$ of the patients with the disease present this sign. In both signs there was loss of data, in some cases due to the presence of the pterygium, covering one of the four images, and others due to the individual's difficulty to have their eyes wide open, and also because of unfocused photographs, which led to lack of clarity in one of the four points necessary to characterize the Cross of Andreas (Table 1).

The prevalence, adjusted for gender and age, is $98 \%$ for the sign of the pancreas and $89 \%$ for the Cross of Andreas.

Table 2 - association between the sign of the pancreas and the variables gender and family history. Logistic Regression Model. São Paulo, SP - April-June, 2006.

\begin{tabular}{lcccc}
\hline & \multirow{2}{*}{ OR } & \multicolumn{2}{c}{ Confidence Interval } & \multirow{2}{*}{$\mathbf{P}$} \\
\cline { 3 - 4 } & & Lower & Upper & \\
\hline Gender & 1.330 & 1.152 & 1.535 & $<0.001$ \\
Family History & & & & $<0.001$ \\
Family History (1) & 3.411 & 3.023 & 3.848 & $<0.001$ \\
\hline
\end{tabular}

Reference categories: gender (female), family history (does not know). Key: Family history (1) - One of the parents has the disease.

Through the Logistic Regression method, the iridologic signs could be analyzed in relation to the study variables and the significant associations could be identified (Tables 2 and 3). Under each table, the reference categories are defined for each variable analyzed, i.e. the category chosen 
to be compared with the others.

In Table 2, significant and positive associations can be observed between the sign of the pancreas and the variables gender and family history.

In Table 3, positive associations between the Cross of Andreas and the variables BMI, family history can be observed, and also a negative association of the Cross of Andreas with the variables gender and physical activity, both statistically significant.

Table 3 - association between the Cross of Andreas and the variables gender, BMI, physical activity and family history. Logistic Regression Model. São Paulo, SP, April to June / 2006.

\begin{tabular}{lcccr}
\hline & \multirow{2}{*}{ OR } & \multicolumn{2}{c}{ Confidence Interval } & \multirow{2}{*}{ P } \\
\cline { 3 - 4 } & & Lower & Upper & \\
\hline Gender & 0.740 & 0.619 & 0.884 & $<0.001$ \\
BMI & & & & $<0.001$ \\
BMI (1) & 5.493 & 4.432 & 6.809 & $<0.001$ \\
BMI (2) & 4.868 & 3.847 & 6.159 & $<0.001$ \\
Physical Activity (1) & 0.817 & 0.684 & 0.976 & 0.026 \\
Family history & & & & $<0.001$ \\
Family history (1) & 2.414 & 1.746 & 3.337 & $<0.001$ \\
Family history (2) & 0.386 & 0.280 & 0.533 & $<0.001$ \\
\hline
\end{tabular}

Reference categories: gender (female), BMI (normal), family history (does not know) and physical activity (sedentary).

Key: BMI (1) - pre-obesity, IMC (2) - obesity 1 and 2; Physical activity (1) - Active; Family history (1) - has a parent with the disease, Family history (2) - does not have a parent with the disease.

\section{DISCUSSION}

The data found in this study corroborate those found by iridologists ${ }^{(2,6-7)}$ : The sign of the pancreas and the Cross of Andreas appeared with high frequencies in individuals with diabetes involved in this research.

The results from Ruas' study ${ }^{(10)}$, which established a parallel between the Cross of Andreas and diabetes, are that this sign is present in $76 \%$ of the patients with the disease. There are methodological differences between the aforementioned study and the present one, especially regarding the tool used to visualize the iris, an important factor in the analysis and recording of the images. In Ruas' study, a $10 \times$ magnifying lens with a flashlight was used, which, in addition to not allowing for greater magnification to study the images, does not register the images to confirm the findings. In the present study, a digital camera with appropriate lenses and lighting was used to analyze the depth of the tissue, besides recording the data for reanalysis and confirmation of the findings with another professional, specialist in the area.

It is important to remember that a positive sign of the pancreas signals the organ's debility instead of specifying the disease. However, the Cross of Andreas is specific for diabetes ${ }^{(2,7)}$.

The risk factors for Diabetes mellitus acknowledged globally are: obesity, sedentarism and heredity. In this research, most individuals studied were seen to maintain a body weight above the WHO-recommended values, are found to be in the sedentary range when the Center for Disease Control - American College of Sports Medicine is used and have a family history of the disease.

The occurrence of significant associations of the variables BMI, physical activity and family history with the Cross of Andreas makes sense, since it is known that obesity, sedentarism and heredity influence the occurrence of diabetes.

The limiting factors of the study were the lack of literature about the topic, which makes the comparison of the results difficult, added to the prejudice and lack of knowledge of some healthcare professionals about complementary therapies (in this case Iris diagnosis), mainly among physicians. This resistance delays research that aims to clarify the strengths and weaknesses of such methods, and indicate how they can be used, along with official Medicine, to contribute to the improvement of the healthcare provided to patients.

\section{CONCLUSIONS}

In the characterization of the studied sample, most were female $(61.9 \%)$, average age was 65 years, BMI between pre-obesity and obesity I (66\%), sedentary $(85 \%)$ and with family histories of diabetes $(61.9 \%)$.

The iridologic signs that the iridologists affirm observing in diabetic individuals were proven in this study. The prevalence rates of the sign of the pancreas and the Cross of Andreas, adjusted for gender and age, were $98 \%$ and $89 \%$, respectively, in the irises of patients with the disease. For the same individual, the prevalence of both signs was $87.8 \%$.

The sign of the pancreas, indicating the organ's debility, has significant associations with gender and family history $(\mathrm{p}<0.001)$.

The sign of the Cross of Andreas, which is specific to reveal Diabetes mellitus, presented significant associations with gender, BMI, physical activity and family history, all of which classical literature appoints as risk factors for the disease.

These are extremely interesting and hope-arousing data for the preventive areas, when it is known that the iris is completely formed by age six. By proving that these iris signs behave as biological markers, it will be easier to find risk groups for diabetes, and finally to really promote the prevention of this disease instead of only preventing its sequels, as it is the case nowadays.

Even though it is an old method, the studies of iridology need to be further developed, with longitudinal studies. What we have are reports of clinical observations, which, although highly valuable, do not satisfy the academic world in which we are inserted. The method is 
promising, since it is one more tool for the identification of risk groups for several diseases, and consequently, the beginning of the implantation of preventive medicine that could not be done yet, due to a series of obstacles, especially since it is difficult to find the risk groups, due to

\section{REFERENCES}

1. Borges-Osório MRL, Robinson WM. Genética humana. 2a ed. Porto Alegre: Artmed; 2001. cap. 1 e 14. p. 17, 307-11.

2. Batello CF. Iridologia e irisdiagnose: o que os olhos podem revelar. 2a ed. São Paulo: Ground; 1999.

3. Nightingale F. Notas sobre enfermagem: o que é e o que não é. São Paulo: Cortez Editora; 1989.

4. Falco SM, Lobo ML. Martha Rogers. In: George JB. Teorias de enfermagem: fundamentos para a prática profissional. Porto Alegre: Artes Médicas; 1993. cap. 14. p.190-204

5. Talento B. Jean Watson. In: George JB. Teorias de enfermagem: fundamentos para a prática profissional. Porto Alegre: Artes Médicas; 1993. cap. 16. p. 254-63

6. Salles LF, Silva MJP. Iridologia: revisão sistemática. In: VIII Congresso Brasileiro de Iridologia e VI International Congress of Irisdiagnosis, 2006, São Paulo. Anais do VI International Congress of Irisdiagnosis, 2006. v. 1. p. 9-9.

7. Beringhs L. Vida saudável pela iridologia. São Paulo: Robel; 1997.

8. Battello C. Iridiologia total. São Paulo: Ground; 1996.

9. Sociedade Brasileira de Diabetes. Consenso Brasileiro sobre Diabetes 2002. Diagnóstico e classificação do diabetes melito e tratamento do diabetes melito tipo 2. Rio de Janeiro: Diagraphic; 2003.

10. Ruas EB. Diabetes mellitus e a Cruz de Andréas [dissertação]. São Paulo: Faculdade de Ciências da Saúde de São Paulo Centro de Ensino Superior de Homeopatia; 2003.

11. World Health Organization (WHO). Diabetes mellitus [Internet]. New York: WHO; 2005 [cited 2005 Jul 13]. Available from: http://www.who.int/mediacentre/factsheets/fs138/en

12. Franco LJ. Epidemiologia do diabetes mellitus. In: Lessa I. $\mathrm{O}$ adulto brasileiro e as doenças da modernidade: epidemiologia das doenças crônicas não transmissíveis. São the cost of genetic exams.

The application of Iris diagnosis is easy, affordable and fast. Thinking in terms of Public Health, the importance of investment in research in this field is quickly noticed.
Paulo (SP): Hucitec; 1998. p. 123-37.

13. World Health Organization (WHO). Prevalence of diabetes worldwide [nternet]. New; WHO: 2005 [cited 2005 Jul 13]. Available from: http://www.who.int/diabetes/facts/ world_figures/en.

14. Secretaria Municipal de Saúde do Rio de Janeiro. Diabetes mellitus: o que é, quais os tipos, conseqüências, tratamento e dicas [texto na internet]. Rio de Janeiro; 2004 [citado 2004 Out 9]. Disponível em: http://www.saude.rio.rj.gov.br

15. Brasil. Ministério da Saúde. Organização Pan-Americana da Saúde. Avaliação do plano de reorganização da atenção à hipertensão arterial e ao diabetes mellitus no Brasil. Brasília: Ministério da Saúde; 2004. p. 13-4.

16. Souza T'T, Santini L, Wada SA, Vasco CF, Kimura M. Qualidade de vida da pessoa diabética. Rev Esc Enferm USP. 1997; 31(1):150-64.

17. Grossi SAA. Prevenção de úlceras nos membros inferiores em pacientes com diabetes mellitus. Rev Esc Enferm USP. 1998; 32(4):377-85.

18. Conselho Federal de Enfermagem. Resolução COFEN n ${ }^{\circ}$ 197/97. Estabelece e reconhece as Terapias Alternativas como especialidade e/ou qualificação do profissional de Enfermagem. In: Documentos básicos de enfermagem. São Paulo: COFEN; 2001. p.159-60

19. São Paulo. Prefeitura da Cidade de São Paulo. Lei n. 13.717, de 08 de Janeiro de 2004. Dispõe sobre a implantação das terapias naturais na Secretaria Municipal de Saúde [Internet]. São Paulo: Secretaria Municipal de Saúde; 2004 [citado 2007 Dez 12]. Disponível em: http://www3.prefeitura.sp.gov.br/cadlem/ s ecretarias / negocios_juridicos/cadlem / pesqnumero.asp?t $=\mathrm{L} \& \mathrm{n}=13717 \& \mathrm{a}=\& \mathrm{~s}=\& \mathrm{var}=0$.

\section{Annex II - Cruz de Andréas}
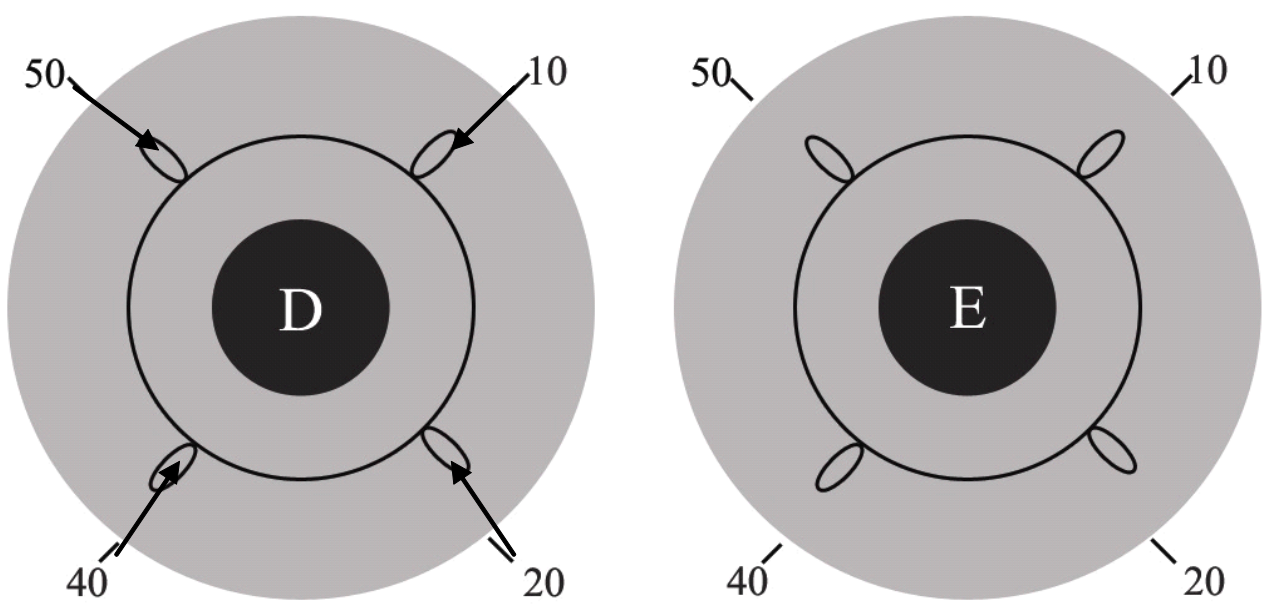

Fonte: Battello C. Iridiologia total. São Paulo: Ed. Ground; $1996^{(8)}$. 


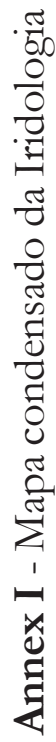
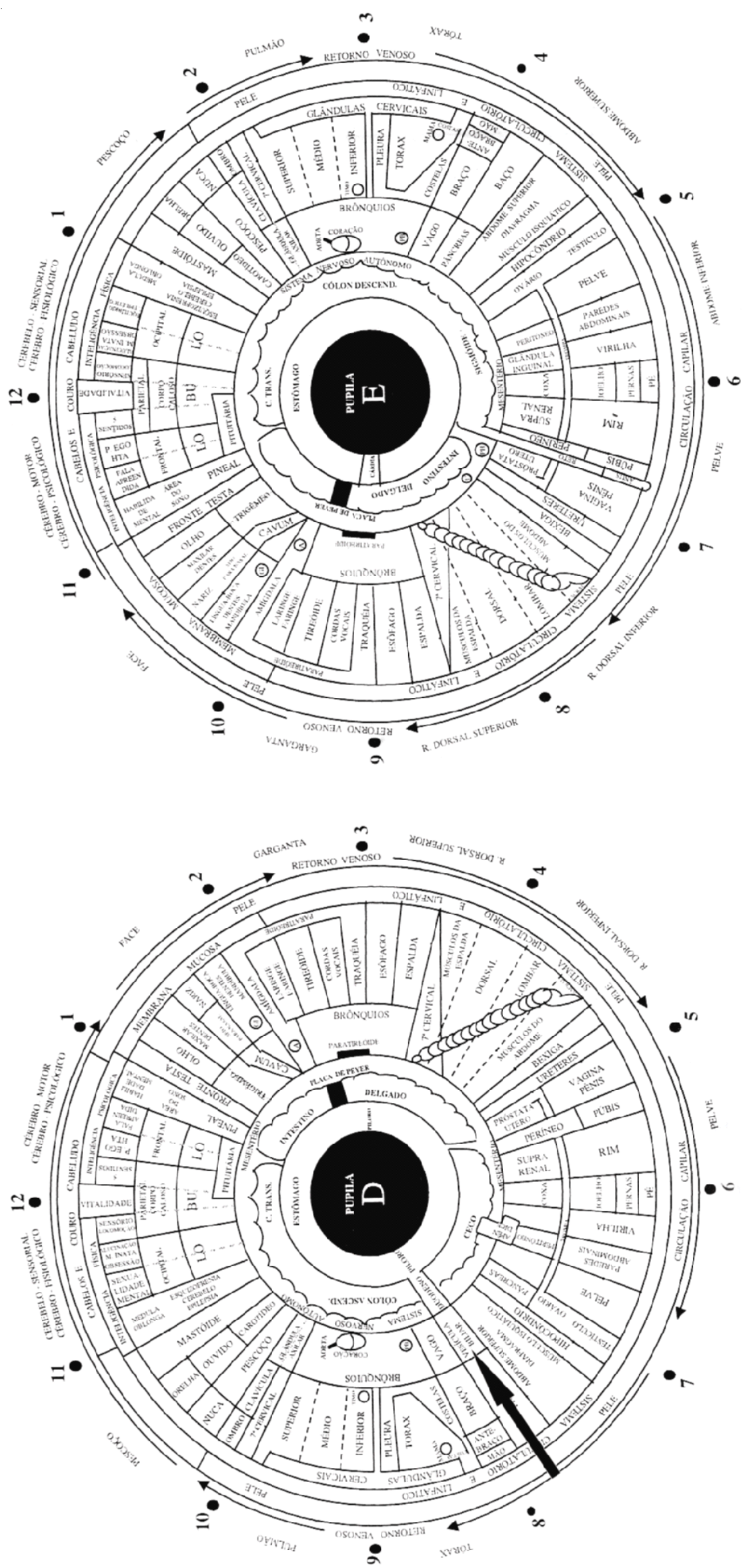

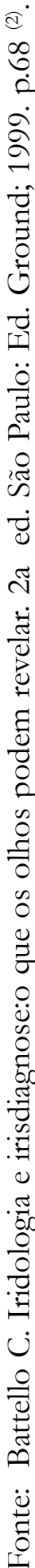

